I have never met a white British person who conceived of him/herself as 'a Caucasian', but the term has of course its proper academic use: when David Lang, the retired Professor of Caucasian Studies at London University, was awarded an honorary doctorate in 1966 it was from the State University of Tbilisi for his work on the Georgian language Georgia, USSR, not Georgia, USA. Can we finally put this arcane term firmly to rest, back on Mount Ararat?

Blumenbach, J. F. (1795) De Generis Varietate Nativa (3rd edn). Göttingen, Germany.

ROLAND LITTLEWOOD University College and Middlesex School of Medicine Department of Psychiatry

Wolfson Building

Middlesex Hospital

London WIN 8AA

EDITOR'S REPLY: It would be more accurate for Dr Littlewood to complain of the continuing use of the term Caucasian in the Journal rather than of the "Journal use of the term". The Journal has no specific policy on this matter.

The potential for introducing error would be great were we to revise the terms under which authors have categorised people. More reflection on the part of authors in their choice of words and use of language would, of course, be welcomed.

\section{Medical Research Council}

SIR: The strategy and initiatives of the Medical Research Council (MRC) have much to commend them and they are lucidly presented by Rees \& Levy (Journal, May 1991, 158, 602-604). They rightly emphasise collaboration and the identification of priorities.

Two main problems arise. The first is that the coordination of genome research has yet to be achieved either globally or even in Europe. The American approach is that the whole genome should be sequenced, while the European view is that research centres should just identify the genes that are actually expressed and then sequence these. Control over genome research in the US has been centralised but this is not so in Europe. Not only are there contrasting approaches between the US and Europe, but they also exist within Europe. The European Science Foundation (ESF) in its latest publication, Report on Genome Research 1991, suggests that it is itself the best forum for co-ordination of European genome research. However, the Human Genome Organiz- ation (HUGO) was specifically organised in 1988 to co-ordinate international research on the genome. According to Nature, Sir Walter Bodmer, President of HUGO, has "reservations about the proposed role of ESF" (Dickman \& Aldous, 1991) and instead favours 'bottom up' co-ordination. Clearly the competing claims of HUGO and ESF for co-ordination of genome research needs early resolution.

The second problem is sustained government underfunding of medical science and the MRC. It is a pity that Rees \& Levy failed to discuss this issue because without sufficient resources, their initiatives are at risk. Both British and American researchers see this underfunding as a form of scientific vandalism. They are not alone. The House of Lords Select Committee on Science and Technology, in its Report of April 1991, said that government investment in science is inadequate. The United Kingdom, of seven nations studied by the Institute for Scientific Information in Philadelphia, has suffered the largest decline in citation of original articles during the 1980 s. The fall in citation was most acute for clinical medicine compared with engineering and applied sciences. According to an editorial in the British Medical Journal, the corporate plan of the MRC for 19911995 is "a plan for decline" (Smith, 1991a). Combined funding from industry and charities now more than doubles the money allocated by the government. Private funding from members of the Association of Medical Research Charities has increased and is expected to overtake that provided by the MRC. Yet there are few formal mechanisms for discussing research priorities with the private sector.

Three conclusions follow. First, it is time that the international debate over whether to sequence the entire 3 million bases of the genome or just the genes (2-3\% of the genome) is settled. Sydney Brenner, head of the MRC Molecular Genetics Unit at Cambridge has publicly advocated that research should concentrate on expressed genes and his view has prevailed in the MRC. However, the National Institutes of Health in Washington DC have opposed a partial approach and argued that the entire genome should be sequenced. Meanwhile in Europe, we cannot afford the luxury of having two organisations with different philosophies co-ordinating the genome project.

Second, the MRC and British researchers could do worse than follow the example of the Australian Society for Medical Research which has raised the public profile of science and successfully campaigned for increased funding of research (Smith, 1991b). Indeed this activist approach is recommended for the entire university system by Sir Eric Ash, Rector of Imperial College, London. $\mathrm{He}$ is the author of a 
pamphlet published in June 1991 by the Committee of Vice-Chancellors and Principals which states that universities face an insidious decline in the standards of teaching and research. He said that universities should take their case to the voters and only by doing so will they "prevent the decline of the university system". In addition, the science lobby in the UK should take advantage of cuts in military expenditure in the UK. This has already happened in the US. In the current fiscal year, the budget for civilian research and development (R \& D) has increased by $10.7 \%$ (or $6 \%$ after inflation) while defence-related R \& D has taken a cut for the second year in a row.

Third, the MRC should broaden its collaboration to include the charities and other research bodies in the development of a comprehensive medical research strategy (Advisory Board for the Research Councils, 1986; British Medical Association, 1990).

AdVISORY BOARD fOR tHE RESEARCH COUNCILS (1986) Report of the Working Party on the Private Sector Funding of Scientific Research (Mathias Committee). London: ABRC.

Dickman, S. \& Aldhous, P. (1991) Helping Europe in human genome research - more coordination needed. Nature, 350, 261.

SMITH, R. (1991a) Strangling the future: the government neglects research at the nation's peril. British Medical Journal, 302, 977-978.

(1991b) Science in Australia: alive, well, kicking and growing. British Medical Journal, 302, 840-842.

Michael MORRIS

Department of Medical and Molecular Genetics Indiana University Medical Centre

975 West Walnut Street

Indianapolis

Indiana 46202-5251

\section{Pathological jealousy defined}

SIR: Mullen's account of jealousy (Journal, May 1991, 158, 593-601) demonstrates the perils of travel through the soul. Without a careful eye on ambivalence one gets lost. The answer to a question he poses can be simply stated: desire for rivalry is the hallmark of pathological jealousy, separating it from zealous engagement in and solicitous guarding of a relationship (normal jealousy). The Concise Oxford Dictionary definition is "jealous - fiercely protective (of rights etc.); afraid, suspicious or resentful of rivalry in love or affection".

Mullen refers to Freud (1955) but misunderstands - projection and reaction formation are not burdens for jealousy as he laments - they are fuels propelling zeal into the realm of disease. Within pathological jealousy lies concealed the wish for a rival to enter or challenge the relationship. Within non-pathological jealousy lies the wish to preserve the relationship. Both forms usually coexist.

How can anyone wish for a rival? Generally these desires fall into three groups (Freud, 1955a,b):

(a) Oedipal, where rivalry enhances the parentlike qualities of the spouse

(b) Homosexual, where rivalry or unfaithfulness permit a less distressing form of awareness of one's own fondness for someone of the same sex

(c) Narcissistic, where one's own self-representation is enhanced by rival's attention to spouse.

These are some ways. There are others. Pathology is proportional to the amount of one's self one sees in the jealousy-provoking situation. What about envy? Looking carefully at individual cases we see it does not occur without self-investment (projection). Sadness and grief do. By understanding the psychodynamics of a given case with an eye on the above and other ambivalent contents, one can separate pathological jealousy from relationship-affirming solicitousness. Once the central discriminant is established, subsidiary questions like "how much zeal is ok?", answer themselves.

FreUd, S. (1955a) Three contributions to the theory of love. In Standard Edition, vol. I/ (ed. J. Strachey), pp. 163-208. London Hogarth Press.

Freud, S. (1955b) Some neurotic mechanisms in jealousy, paranoia and homosexuality. In Standard Edition, vol. II (ed. J. Strachey), pp. 221-232. London: Hogarth Press.

Medical Center of Hospital of Vermont
Burlington

RICHARD KAST

Vermont, USA

\section{Access to health records}

SIR: Gaitonde (Journal, July 1991, 159, 164) is right to draw our attention to the likely impact of the Access to Health Records Act, 1990, but his pessimistic conclusion that record keeping may be inhibited to the detriment of patient care is disappointing. His prediction of a defensive response from the profession may well come true and was documented in response to the UK Data Protection Act (1987) by Jones et al (1988). These authors audited the censoring of information disclosed to patients by doctors in computerised records in a diabetic clinic and found that $69 \%$ of the problems which had been censored out could, on 